\title{
Mating-Related Stimulation Induces Phosphorylation of Dopamine- and Cyclic AMP-Regulated Phosphoprotein-32 in Progestin Receptor-Containing Areas in the Female Rat Brain
}

\author{
John M. Meredith, ${ }^{1}$ Christopher A. Moffatt, ${ }^{2}$ Anthony P. Auger, ${ }^{2}$ Gretchen L. Snyder, ${ }^{3}$ Paul Greengard, ${ }^{3}$ and \\ Jeffrey D. Blaustein² \\ 1 Division of Neurotoxicology, National Center for Toxicological Research, United States Food and Drug Administration, \\ Jefferson, Arkansas 72079, ${ }^{2}$ Center for Neuroendocrine Studies, University of Massachusetts, Amherst, Massachusetts \\ 01003, and 3Laboratory of Molecular and Cellular Neuroscience, Rockefeller University, New York, New York 10021
}

\begin{abstract}
Vaginal-cervical stimulation induces a number of physiological and behavioral events, including the facilitation of mating behavior. Although the facilitation of one component of mating behavior, lordosis, by vaginal-cervical stimulation does not require the presence of progesterone, it appears to be mediated by neural progestin receptors. Abundant evidence suggests that dopamine may play a role in the neural circuitry activated by vaginal-cervical stimulation, including the mating-induced release of dopamine in progestin receptor-containing areas of the brain, changes in the activational state of progestin receptors because of dopamine $D_{1}$ receptor stimulation, facilitation of lordosis by $D_{1}$ receptor stimulation in estradiol-primed rats via progesterone-independent events, and $D_{1}$ agonist-induced neuronal responses in progestin receptor-containing areas and cells. We tested the hypothesis that vaginal-cervical stimulation induces phosphorylation of dopamine- and cyclic AMPregulated phosphoprotein (DARPP-32; $M_{r}=32,000$ ), a protein phosphorylated predominantly in response to the stimulation of
\end{abstract}

$D_{1}$ receptors. At $9 \mathrm{~d}$ after ovariectomy, female rats were injected subcutaneously with a behaviorally effective dose of estradiol benzoate. At $48 \mathrm{hr}$ later they received vaginal-cervical or control (perineal) stimulation, and they were perfused $1 \mathrm{hr}$ later. Vaginal-cervical stimulation increased the number of cells expressing pDARPP-32 immunoreactivity by $92 \%$ in the medial preoptic nucleus, $134 \%$ in the caudal ventromedial hypothalamic nucleus, $123 \%$ in the posterodorsal medial amygdala, and $103 \%$ in the bed nucleus of the stria terminalis. These results suggest that some of the neuronal effects of vaginalcervical stimulation, and perhaps other social or environmental stimuli, are mediated by phosphorylation of DARPP-32, perhaps via stimulation of $D_{1}$ receptors, within progestin receptorcontaining areas.

Key words: vaginal-cervical stimulation; cervical stimulation; dopamine; estradiol; progestin receptors; phosphorylation; DARPP-32
Somatosensory stimulation of the vagina and cervix (VCS) produces a variety of physiological and behavioral responses, including prolactin release (Smith et al., 1975), progesterone release (Smith et al., 1975), an increase in analgesia (Komisaruk and Wallman, 1977), and acute facilitation of lordosis (Komisaruk and Diakow, 1973), followed by longer latency inhibition of sexual receptivity (Blandau et al., 1941).

During the estrous cycle the timing and duration of sexual behaviors are determined by the sequential release of estradiol, followed by progesterone (Boling and Blandau, 1939; Powers, 1970). These behaviors are abolished after ovariectomy. Although estradiol alone can induce lordosis in ovariectomized rats, the addition of progesterone after estradiol enables lower doses of estradiol to be effective (Whalen, 1974), more tightly regulates the onset and termination of sexual behaviors, and induces the full range of sexual behaviors, including solicitational behaviors (Erskine, 1989).

\footnotetext{
Received July 10, 1998; revised Sept. 10, 1998; accepted Sept. 16, 1998.

This research was supported by MH10650 to J.M.M., HD08181 to C.A.M., MH11392 to A.P.A., MH 40899 and DA 10044 to P.G., and Senior Scientist Award MH01312 and NS19327 to J.D.B. all from National Institutes of Health. We gratefully acknowledge Robin Lempicki for her expert technical assistance.

Correspondence should be addressed to Dr. Jeffrey D. Blaustein, Center for Neuroendocrine Studies, Tobin Hall, Box 37720, University of Massachusetts, Amherst, MA 01003.

Copyright (C) 1998 Society for Neuroscience $\quad 0270-6474 / 98 / 1810189-07 \$ 05.00 / 0$
}

Mating stimulation, including VCS, increases the expression of lordosis in estradiol-primed rats in the absence of circulating progesterone (Komisaruk, 1972; Hardy and DeBold, 1973). The progesterone-independent induction of lordosis by VCS appears to be mediated by progestin receptors, because it can be blocked with progesterone antagonists (Auger et al., 1997). VCS increases metabolic activity (Allen et al., 1981), alters electrophysiological activity (Chan et al., 1984), and increases immediate early gene expression (Erskine, 1993; Flanagan et al., 1993; Pfaus et al., 1993; Rowe and Erskine, 1993; Tetel et al., 1993) in several hypothalamic areas, including the medial preoptic nucleus (MPO), arcuate hypothalamic nucleus (Arc), ventromedial hypothalamic nucleus (VMH), medial amygdaloid nucleus ( $\mathrm{Me})$, and bed nucleus of the stria terminalis (BST). In fact, a subpopulation of neurons within the $\mathrm{VMH}$ that respond to VCS contains progestin receptors (Auger et al., 1996).

Dopamine is a candidate neurotransmitter in the neuronal pathways mediating the VCS-induced progesterone-independent expression of lordosis. For example, dopamine is released in the striatum of rats and hamsters (Meisel et al., 1993; Pfaus et al., 1995) and the nucleus accumbens (Pfaus et al., 1995) and ventrolateral VMH of rats (Vathy and Etgen, 1989) after either mating or experimenter-induced VCS. In addition, the stimulation of $\mathrm{D}_{1}$ dopamine receptors alters the activational state of progestin receptors in vitro (Power et al., 1991) and induces lordosis via a 
progestin receptor-mediated pathway in estradiol-primed female rats (Mani et al., 1994; Apostolakis et al., 1996). Finally, $\mathrm{D}_{1}$ receptor agonists induce the expression of protein products of immediate early genes (e.g., Fos) in progestin receptorcontaining cells in the hypothalamus (Meredith et al., 1997).

We tested the hypothesis that VCS induces the phosphorylation of a protein associated with the presence of $D_{1}$ receptors, DARPP-32. DARPP-32 is a dopamine- and cAMP-regulated phosphoprotein, the distribution of which is highly correlated with the cellular presence of $\mathrm{D}_{1}$ receptors (Hemmings et al., 1987). DARPP-32 is phosphorylated in response to several neurotransmitters, of which dopamine appears to be the most common (Walaas et al., 1983; Walaas and Greengard, 1984; Tsou et al., 1993; Snyder et al., 1994; Desduoits et al., 1995). Once DARPP-32 is phosphorylated, it inhibits phosphatase-1, which results in the increased phosphorylation of other proteins (Greengard et al., 1998). Thus, one step by which dopamine $\mathrm{D}_{1}$ receptor stimulation may lead to the activation of progestin receptors is via the phosphorylation of DARPP-32 (Power et al., 1991). Finally, DARPP-32 is located in several areas associated with the regulation of sexual behavior, including the amygdala (Ouimet et al., 1984; Barbas et al., 1993), the bed nucleus of the stria terminalis (Ouimet et al., 1984), and the ventromedial hypothalamus (Ouimet et al., 1984). Based on these observations, the phosphorylated form of DARPP-32 may offer a more specific means to examine responses that potentially are mediated by $\mathrm{D}_{1}$ receptors.

\section{MATERIALS AND METHODS}

Animals. Female CD VAF Sprague Dawley rats (200-250 gm) were obtained from Charles River Breeding Laboratories (Kingston, NY). Animals were group-housed four per cage in stainless steel cages. Animals were maintained on a 14:10 light/dark cycle, with lights on from 9:00 P.M. to 11:00 A.M. and the temperature maintained at $\sim 22^{\circ} \mathrm{C}$. Food (Lab Diet 5001, Rodent Diet, PMI Feed, St. Louis, MO) and water were available ad libitum. All animals were maintained under these conditions for 7-10 d before ovariectomy.

Experimental protocol. All rats were ovariectomized under methohexital sodium anesthesia $(52 \mathrm{mg} / \mathrm{kg}$ birth weight; Brevital, Eli Lilly, Indianapolis, IN) to eliminate endogenous gonadal steroids. At $9 \mathrm{~d}$ after surgery the animals were injected subcutaneously with $2 \mu \mathrm{g}$ of estradiol benzoate (EB; 1:00 P.M.). At 47-49 hr later (12:00-2:00 P.M.) rats received either VCS $(n=4)$ or a control stimulation consisting of stimulation of the perineal area $(n=4)$. Experimenter-induced stimulation was performed during the dark phase of the light cycle. Stimulation was administered with a $1 \mathrm{cc}$ plastic syringe plunger attached to a force gauge (FDN5, Wagner Instruments, Greenwich, CT). Each session of stimulation consisted of $2 \mathrm{sec}$ of stimulation every $30 \mathrm{sec}$ for $15 \mathrm{~min}$. VCS-stimulated animals received $300 \mathrm{~g}$ of force on the vagina and cervix, whereas control animals received $300 \mathrm{~g}$ of force on the perineal area. At $1 \mathrm{hr}$ after termination of VCS (12:15-2:15 P.M.), the animals were perfused with $2 \%$ acrolein. Brain sections were processed for immunocytochemical detection of the phosphorylated form of DARPP-32.

Perfusion. All animals were injected with a lethal combination dose of pentobarbital $(8.9 \mathrm{mg})$ and chloral hydrate $(42.5 \mathrm{mg})$. When the animals were anesthetized deeply, the thoracic cavity was exposed, the thoracic aorta and posterior vena cava were clamped, and $1 \mathrm{ml}$ of saline containing $5000 \mathrm{IU}$ of heparin was injected into the left ventricle. Incisions were made in the right atrium and the left ventricle, followed by insertion of a cannula through the left ventricle into the aorta. Physiological saline (25 $\mathrm{ml}$ ) was flushed through the brain before the flow of $2 \%$ acrolein (in 0.1 $\mathrm{M} \mathrm{NaPO}_{4}$ buffer; $\mathrm{pH}$ 7.2) began. Perfusion pressure was maintained at $\sim 100 \mathrm{~mm}$ of $\mathrm{Hg}$ at a flow rate of $25 \mathrm{ml} / \mathrm{min}$ for $14 \mathrm{~min}$. After their removal from the cranium, the blocked brains were stored overnight at $4^{\circ} \mathrm{C}$ in $0.1 \mathrm{M}$ sodium phosphate buffer $\left(\mathrm{pH} 7.2\right.$ at $\left.4^{\circ} \mathrm{C}\right)$ containing $20 \%$ sucrose. The $40 \mu \mathrm{m}$ sections were cut through the forebrain with a freezing rotary microtome and were stored in cryoprotectant at $-20^{\circ} \mathrm{C}$ until preparation for immunocytochemistry.

Diaminobenzidine immunocytochemistry for pDARPP-32. For each animal a set of one in four sections was removed from cryoprotectant and rinsed in $0.5 \mathrm{M}$ Tris-buffered saline (TBS; $\mathrm{pH} \mathrm{7.6}$, at $22^{\circ} \mathrm{C}$ ). Then the sections were pretreated in $1 \%$ sodium borohydride to remove residual aldehydes. After pretreatment and additional rinses in TBS, the sections were placed into $1 \% \mathrm{H}_{2} \mathrm{O}_{2}, 20 \%$ normal goat serum, and $1 \%$ bovine serum albumin to reduce nonspecific staining and endogenous peroxidase activity. The sections were incubated with an antibody (mAb-23; 1:6000 dilution) generated against a 10 amino acid peptide encompassing the sequence of rat DARPP-32 phosphorylated on threonine (Snyder et al., 1992), which is selective for the phosphorylated form of DARPP-32. The antibody was diluted in modified TBS (mTBS; $\mathrm{pH} 7.6,4^{\circ} \mathrm{C}$ ) containing $0.1 \%$ gelatin, $0.02 \%$ sodium azide, $0.5 \%$ Triton $\mathrm{X}-100$, and $1 \%$ normal goat serum; the incubation was for $3 \mathrm{~d}$ at $4^{\circ} \mathrm{C}$. After rinses with mTBS buffer $\left(\mathrm{pH} 7.6,22^{\circ} \mathrm{C}\right)$ the tissue sections were incubated in secondary antiserum ( $3 \mu \mathrm{g} / \mathrm{ml}$, biotinylated goat anti-mouse, lot number 20979; Jackson ImmunoResearch, West Grove, PA) diluted in mTBS $\left(\mathrm{pH} 7.6,22^{\circ} \mathrm{C}\right)$ for $90 \mathrm{~min}$ at room temperature. After rinses in mTBS $\left(\mathrm{pH} 7.6,22^{\circ} \mathrm{C}\right)$ and $\mathrm{TBS}$, the sections were incubated for $90 \mathrm{~min}$ at room temperature in avidin DH/biotinylated horseradish peroxidase $\mathrm{H}$ (Vectastain Elite Kit; Vector Laboratories, Burlingame, CA). After rinses in TBS, the sections were treated with diaminobenzidine $(0.05 \%$ in TBS) in the presence of $\mathrm{H}_{2} \mathrm{O}_{2}(0.05 \%)$ for $\sim 10 \mathrm{~min}$ and then rinsed twice in TBS. All pDARPP-32 immunostaining was eliminated by the omission of primary antibody from the immunocytochemical procedure (Fig. 1).

In addition to the phosphorylated form of DARPP-32, in Western blots the primary antibody (mAb-23) detects the phosphorylated form of inhibitor-1 as well as two cross-reactive bands of higher molecular weight ( $\sim 100$ and $70 \mathrm{kDa})$. In a Western blot analysis that used tissue blocks of combined hypothalamus and preoptic area from ovariectomized, estradiol-primed animals that did not receive VCS, clear evidence was obtained for the presence of phosphorylated DARPP-32 and the higher molecular weight proteins, but not of phosphorylated inhibitor-1 with the use of the mAB-23 antibody (A. Auger, J. Meredith, G. Snyder, P. Greengard, J. Blaustein, unpublished observations). Although Western analysis failed to detect a VCS-induced increase in immunoreactivity for the phosphorylated form of DARPP-32, this negative result is likely to be attributable to the relatively small population of cells in which an increase in pDARPP-32 immunoreactivity is seen with immunocytochemistry. In another study, however, we observed that an estradiol injection, which induces increases in phosphorylated DARPP-32 as seen by immunocytochemical staining, also increased the immunoreactivity of the phosphorylated DARPP-32 band, but not that of the other bands (A. Auger, J. Meredith, G. Snyder, P. Greengard, J. Blaustein, unpublished observations). This latter result suggests that the mAb-23 antibody can be used reliably in immunocytochemical studies for the detection of phosphorylated DARPP-32.

Areas analyzed. Nine areas throughout the female rat forebrain were examined bilaterally for the induction of pDARPP-32-like immunoreactivity by VCS (Fig. 2). The areas were chosen either because they contain high levels of DARPP-32 or of estradiol-induced progestin receptors. They included the medial preoptic nucleus (MPO); the rostral, mid-, and caudal aspects of the ventromedial hypothalamic nucleus, ventrolateral (rVMHVL, mVMHVL, and cVMHVL); the ovarian steroid receptorcontaining area associated with the rVMHVL (rVMHVL-ORA); the medial amygdaloid nucleus (Me); the central amygdaloid nucleus, lateral $(\mathrm{CeL})$; the bed nucleus of the stria terminalis (BST); and the arcuate hypothalamic nucleus (Arc). Bilateral measurements consisting of $600 \times$ $800 \mu \mathrm{m}$ areas were analyzed for the MPO, rVMHVL-ORA, Me, CeL, and BST. The VMHVL areas analyzed consisted of bilateral $313 \times 375$ $\mu \mathrm{m}$ areas. The shape and size of the area analyzed in the Arc were determined by phase-contrast microscopy and did not differ significantly between sections.

Computer-assisted image analysis. Computer-assisted image analysis was done with a Leitz Dialux 20 microscope (Ernst Leitz, Wetzler GMBH, Germany) attached to a MTI CCD 72 camera (DAGE MTI, Michigan City, IN), which was connected to a Macintosh Quadra 700 (Apple Computer, Cupertino, CA). The Image 1.55 program (developed at National Institutes of Health and available on the Internet at http:// rsb.info.nih.gov/nih-image/) was used for all image processing and analysis.

Before each imaging session the microscope was adjusted for Kohler illumination by using $10 \times$ magnification. The microscope and camera were focused on an opaque area of a coverslipped slide. Camera gain and black levels were adjusted so that the clear portion of the slide produced gray levels within the single digits while the opaque area produced a gray level of 255. This effectively calibrated the camera to use the full range 


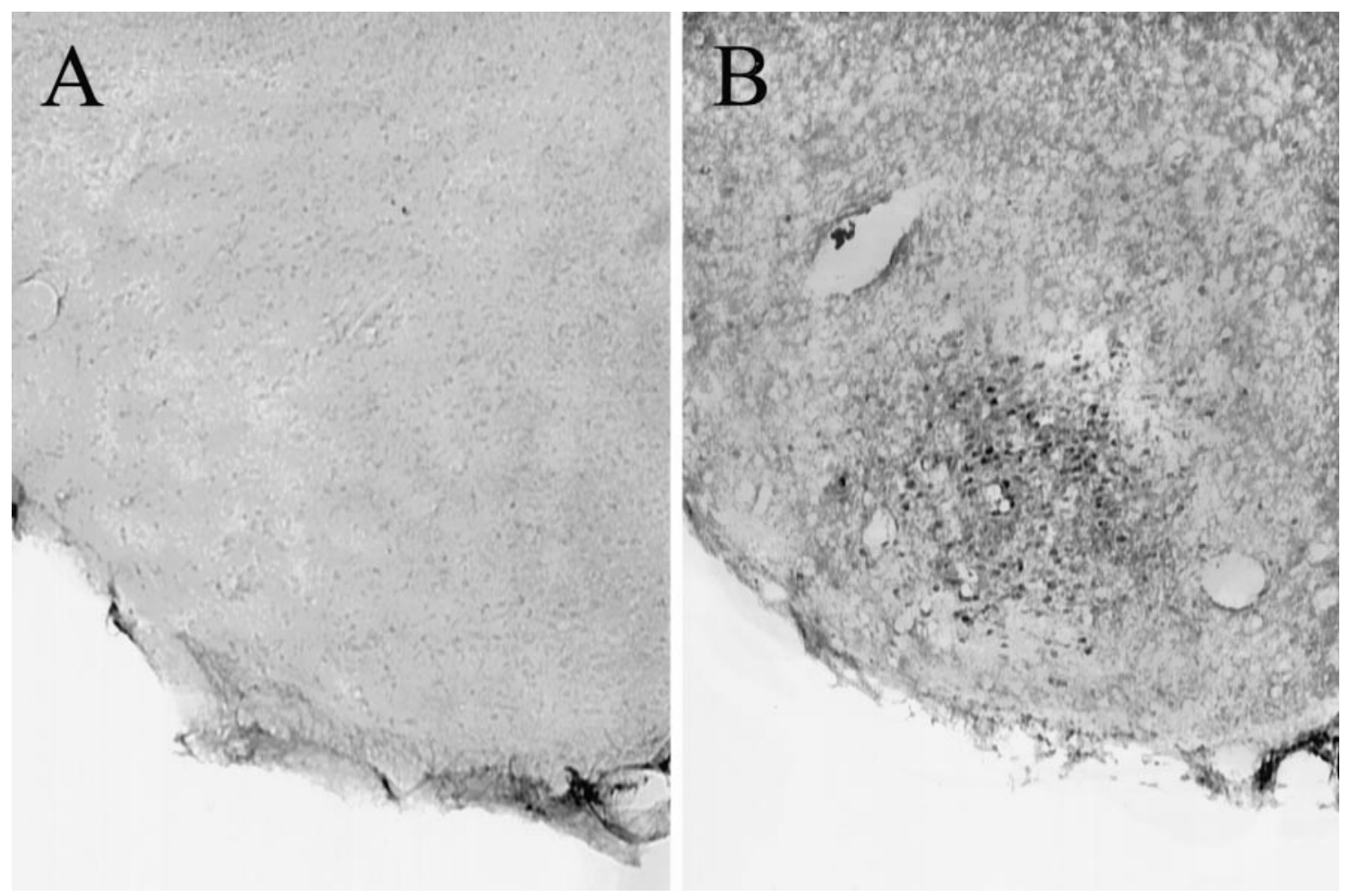

Figure 1. Photomicrographs of the cVMHVL incubated in the absence $(A)$ or presence $(B)$ of pDARPP-32 primary antibody. Tissue was derived from an ovariectomized, estradiol-treated female rat receiving experimenter-induced VCS.

of gray levels ( $0-255$, with 0 being white and 255 being black). All images for an area were taken during the same session.

Objects were excluded from analysis if they were $<10$ pixels or $>200$ pixels in area at $10 \times$ magnification. The average gray level and the SD were obtained for the area analyzed within each image. Then the density threshold option was set to a maximum of 3.5 SDs above the mean gray level and a minimum gray level of 1 . This effectively eliminated the influence of foreground immunostaining in the calculation of background gray level. A new mean and SD were determined with this setting, and the density threshold option was set to a minimum of 3.5 SDs above the new average gray level and a maximum gray level of 255. This procedure effectively determined the mean gray levels of the background area, excluding the contribution of foreground immunoreactivity. Total cell numbers for each image were analyzed, with the experimenter blind to the treatment groups.

Data analysis and statistics. Data collected from image analysis were analyzed on the basis of whether the number of pDARPP32-immunoreactive (pDARPP-32-IR) cells was affected by treatment. Two-tailed Student's $t$ tests were run to contrast animals receiving VCS with those that did not. Contrasts were considered statistically significant at $p<0.05$.

\section{RESULTS}

pDARPP-32-like immunoreactivity appeared to be localized primarily in the cytoplasmic region of the cells, although there appeared to be some nuclear immunostaining within certain areas such as the MPO. Although pDARPP-32-IR cells were found in the MPO, rVMHVL, mVMHVL, cVMHVL, rVMHVLORA, Me, CeL, BST, and Arc, VCS increased the number of pDARPP-32-IR cells in four of the areas that were studied (Fig. $3)$. More specifically, VCS significantly increased the number of pDARPP-32-IR cells in the MPO (92\% increase), cVMHVL (134\% increase), Me (121\% increase), and the BST (102\% increase). There was also evidence of increased immunostaining of nonsomatic tissue within the caudal portion of the VMHVL after VCS. Representative photomicrographs of pDARPP-32 immunostaining in the cVMHVL after VCS and after control stimulation are shown in Figure 4. In contrast, VCS did not influence pDARPP-32 immunostaining in the rostral and mid portions of the VMHVL, the rVMHVL-ORA, CeL, or the Arc.

\section{DISCUSSION}

The results suggest that VCS increases the phosphorylation of DARPP-32 in specific areas of the female rat brain. In particular, experimenter-induced VCS increased immunostaining for phosphorylated DARPP-32 in the medial preoptic nucleus, the caudal aspect of the ventrolateral-ventromedial hypothalamic nucleus, the medial amygdaloid nucleus, and the bed nucleus of stria terminalis. Interestingly, each of these areas is involved in the hormonal regulation of female sexual behavior in rats (Moss and Foreman, 1976; Foreman and Moss, 1979; Lopez and Carrer, 1982; Blaustein and Olster, 1989; Rajendren and Moss, 1993; Pfaff et al., 1994), and each area contains an abundance of estradiol-induced progestin receptors (Parsons et al., 1982). Areas in which changes in the phosphorylation of DARPP-32 were not seen after VCS include the more rostral areas of the ventrolateral-ventromedial nucleus of the hypothalamus, the central nucleus of the amygdala, and the arcuate nucleus of the hypothalamus.

There is much evidence that DARPP-32 is phosphorylated in response to the stimulation of $\mathrm{D}_{1}$ receptors (Walaas et al., 1983; Walaas and Greengard, 1984; Hemmings et al., 1987). Incubation with dopamine increased the phosphorylation of DARPP-32 in slices of intact male rat neostriatum (Walaas et al., 1983; Walaas and Greengard, 1984). Cyclic AMP also increased the phosphorylation of DARPP-32 in this preparation (Walaas et al., 1983; Walaas and Greengard, 1984). Because $\mathrm{D}_{1}$ receptor stimulation results in an increase in cyclic AMP levels $\left(D_{2}\right.$ receptor stimula- 

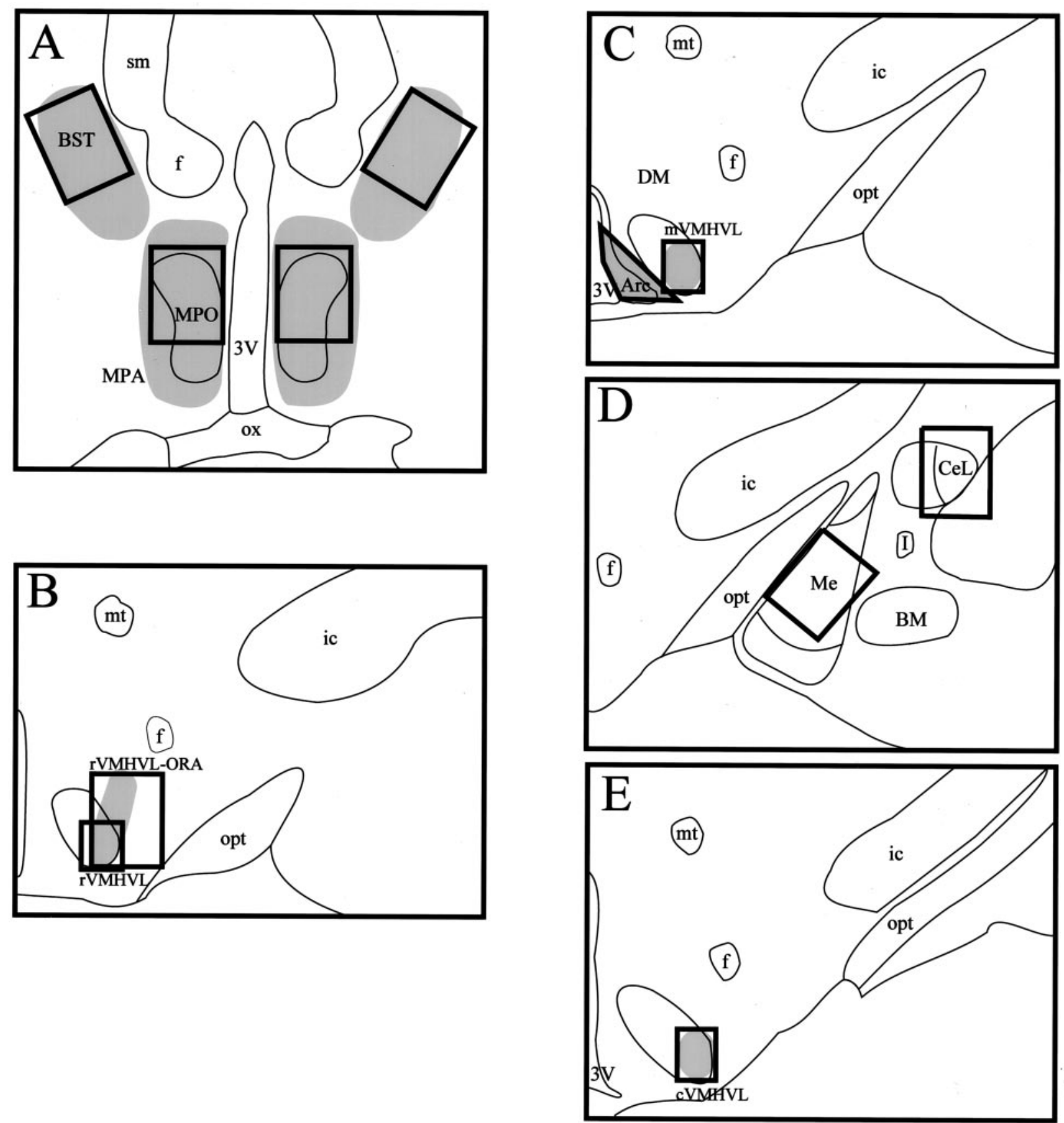

Figure 2. Composite drawings of sections that were analyzed from the BST and MPO $(A), \mathrm{rVMHVL}-\mathrm{ORA}$ and rVMHVL $(B)$, mVMHVL and Arc $(C)$, Me and CeL $(D)$, and cVMHVL $(E)$. Shading represents areas containing progestin receptor-IR cells within and continuous with the areas analyzed. $3 V$, Third ventricle; $A r c$, arcuate hypothalamic nucleus; $B M$, basomedial amygdaloid nucleus; $B S T$, bed nucleus of the stria terminalis; $C e L$, central amygdaloid nucleus, lateral; $c V M H V L$, caudal ventromedial hypothalamic nucleus, ventrolateral; $D M$, dorsomedial hypothalamic nucleus; $f$, fornix; $I$, intercalated nuclei amygdala; $i c$, internal capsule; $M e$, medial amygdaloid nucleus; $M P A$, medial preoptic area; $M P O$, medial preoptic nucleus; $m t$, mamillothalamic tract; $m V M H V L$, mid-ventromedial hypothalamic nucleus, ventrolateral; opt, optic tract; ox, optic chiasm; $r V M H V L$, rostral ventromedial hypothalamic nucleus, ventrolateral; $r V M H V L-O R A$, the ovarian receptor-containing area associated with the rVMHVL that extends dorsolaterally toward the fornix; sm, stria medullaris thalamus.

tion is associated with decreases in cyclic AMP), these data suggest that the dopaminergic phosphorylation of DARPP-32 is attributable to the stimulation of dopamine $\mathrm{D}_{1}$ receptor subtypes (Walaas et al., 1983). We recently have observed that intracerebral administration of the $\mathrm{D}_{1}$ agonist SKF-38393 increased pDARPP-32 immunoreactivity in the caudal aspect of the ventrolateral-ventromedial nucleus of the hypothalamus (our unpublished observations). Taken together, these results suggest that the stimulation of dopamine $\mathrm{D}_{1}$ receptors is an important mechanism by which DARPP-32 is phosphorylated.

Although phosphorylation of DARPP-32 is associated most often with the activation of $\mathrm{D}_{1}$ receptors, it is possible that factors other than dopamine may phosphorylate DARPP-32. Indeed, DARPP-32 in epithelial cells of the choroid plexus is phosphorylated after treatment with forskolin, isoproterenol, vasoactive intestinal peptide, atrial natriuretic peptide, or serotonin, but not 


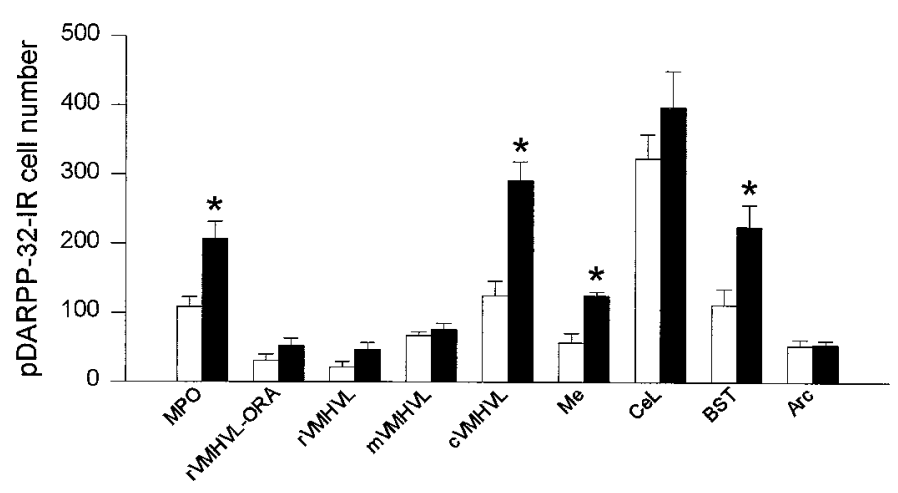

Figure 3. Effects of experimenter-induced VCS on pDARPP-32 cell number in female rat brain. Open bars, Control stimulation; filled bars, VCS. See Figure 2 for nomenclature. ${ }^{*} p<0.05$ when compared with matched controls.

by dopamine (Snyder et al., 1992). Although virtually all $\mathrm{D}_{1}$ receptor-immunoreactive cells in the caudate putamen also contain DARPP-32 immunoreactivity, not all DARPP-32immunoreactive cells contain $\mathrm{D}_{1}$ receptor immunoreactivity. However, $>50 \%$ of DARPP-32-immunoreactive cells also contain $\mathrm{D}_{1}$ receptor immunoreactivity (Langley et al., 1997). Therefore, although evidence from a variety of studies suggests that phosphorylation of DARPP-32 by VCS is attributable to $\mathrm{D}_{1}$ receptor stimulation, it is possible that the stimulation of another receptor family is responsible for the increase in pDARPP-32 immunoreactivity.

The regional distribution of DARPP-32 follows the general pattern of dopaminergic innervation (Ouimet et al., 1984; Walaas and Greengard, 1984), and DARPP-32 does not appear to be localized within dopamine-containing cells or dendrites (Ouimet et al., 1984). Furthermore, DARPP-32 distribution is consistent with $\mathrm{D}_{1}$ receptor distribution (Hemmings et al., 1987). For example, $\mathrm{D}_{1}$ receptor binding (Boyson et al., 1986; Mansour et al., 1990), $\mathrm{D}_{1 \mathrm{a}}$ immunoreactivity (Huang et al., 1992; Levey et al., 1993; Ariano and Sibley, 1994), and the expression of $\mathrm{D}_{1 \mathrm{a}} \mathrm{mRNA}$ (Fremeau et al., 1991; Weiner et al., 1991) are found in the preoptic area, ventromedial nucleus of the hypothalamus, and the amygdala, all of which contain VCS-induced pDARPP-32 immunoreactivity. $\mathrm{D}_{1 \mathrm{~b}}$ receptor subtype $\mathrm{mRNA}$ also has been reported in the rat hypothalamus (Sunahara et al., 1991).

Mating stimuli in rats result in a variety of physiological and behavioral changes that include the induction of pseudopregnancy (Smith et al., 1975), facilitation of lordosis (Komisaruk, 1972; Hardy and DeBold, 1973; Komisaruk and Diakow, 1973), a subsequent decrease in the duration of sexual receptivity (Blandau et al., 1941), and an increase in analgesia (Crowley et al., 1976). Particularly intriguing is the finding that the induction of lordosis occurs in the absence of progesterone and yet is inhibited by the administration of a progesterone antagonist, RU 486 (Auger et al., 1997). This finding suggests that VCSinduced lordosis is progesterone-independent, yet progestin receptor-dependent.

Several lines of evidence suggest that dopamine may be a candidate for mediating progesterone-independent facilitation of lordosis by VCS. It is well established that dopamine or dopamine agonists facilitate lordosis in estradiol-primed female rats (Foreman and Moss, 1979). Furthermore, intracerebral administration of $\mathrm{D}_{1}$ agonists appears to facilitate lordosis via a progestin receptor-mediated event (Mani et al., 1994). This is supported by the observation that dopamine can alter progestin receptormediated gene transcription in vitro via phosphorylationdependent mechanisms (Power et al., 1991, 1992). One of the phosphoproteins that has been suggested (Power et al., 1991) for the $\mathrm{D}_{1}$-specific alterations in progestin receptor gene expression is DARPP-32. In fact, facilitation of lordosis by either progesterone or $\mathrm{D}_{1}$ agonists is blocked in mice homozygous for a disrupted DARPP-32 gene (S. K. Mani, personal communication with permission). This is consistent with our observations that VCS induces lordosis and increases pDARPP-32 immunoreactivity and with the hypothesis that these effects are attributable to the stimulation of $\mathrm{D}_{1}$ receptor-containing neurons.

Mating stimuli, including VCS, result in the release of dopamine in various brain regions, including the nucleus accumbens, striatum and ventromedial hypothalamus of rats (Vathy and Etgen, 1989; Pfaus et al., 1995), and the ventral striatum of hamsters (Meisel et al., 1993). We recently have examined rat forebrain areas that are responsive to stimulation by $\mathrm{D}_{1}$ receptors. Intracerebral injection of the $\mathrm{D}_{1}$ agonist, SKF-38393, increased Fos expression in progestin receptor-containing areas in female rats, including the ventrolateral-ventromedial nucleus of the hypothalamus, the medial preoptic nucleus, and the arcuate nucleus of the hypothalamus (Meredith et al., 1997). Furthermore, a small population of progestin receptor-containing cells in the caudal aspect of the ventrolateral-ventromedial hypothalamic nucleus responded to $\mathrm{D}_{1}$ receptor stimulation with increased Fos-IR (Meredith et al., 1997). These observations, in conjunction with the present results, suggest that VCS may release dopamine into specific progestin receptor-containing areas and cells of the forebrain. The stimulation of $\mathrm{D}_{1}$ receptors in these progestin receptor-containing areas may activate progestin receptors, leading to changes in the expression of lordosis.

It is also possible that changes in the phosphorylation of DARPP-32 may relate to other effects of VCS, including the induction of pseudopregnancy, increased analgesia, and heat abbreviation. For example, VCS induces prolactin release associated with pseudopregnancy (Smith et al., 1975). The amygdala is critical for the release of prolactin during pseudopregnancy (Coopersmith et al., 1996), and it is an area in which VCS induced pDARPP-32-IR expression. Finally, although the involvement of dopamine in VCS-induced analgesia (Crowley et al., 1977) and the regulation of heat abbreviation is unclear, the present results do not preclude the possibility that VCS-induced phosphorylation of DARPP-32 (possibly via $\mathrm{D}_{1}$ receptor stimulation) might contribute to these responses as well.

In addition to causing the phosphorylation of DARPP-32, VCS affects other markers of neuronal response such as the expression of immediate early genes, metabolic activity, and electrophysiological activity. These changes in neuronal response occur in many of the same areas in which VCS induces the phosphorylation of DARPP-32. For example, VCS increases the expression of the immediate early gene, Fos, in the medial preoptic nucleus, bed nucleus of stria terminalis, medial amygdaloid nucleus, ventromedial hypothalamus, arcuate hypothalamic nucleus, and central amygdaloid nucleus, lateral (Erskine, 1993; Flanagan et al., 1993; Pfaus et al., 1993; Rowe and Erskine, 1993; Tetel et al., 1993; Auger et al., 1996). VCS also increases the expression of the immediate early gene EGR-1 in the medial amygdaloid nucleus, medial preoptic nucleus, bed nucleus of stria terminalis, and ventrolateral-ventromedial hypothalamic nucleus (Polston and Erskine, 1995). VCS increases metabolic activity (assessed by measuring the uptake of ${ }^{14} \mathrm{C}$-deoxyglucose) in the medial preop- 

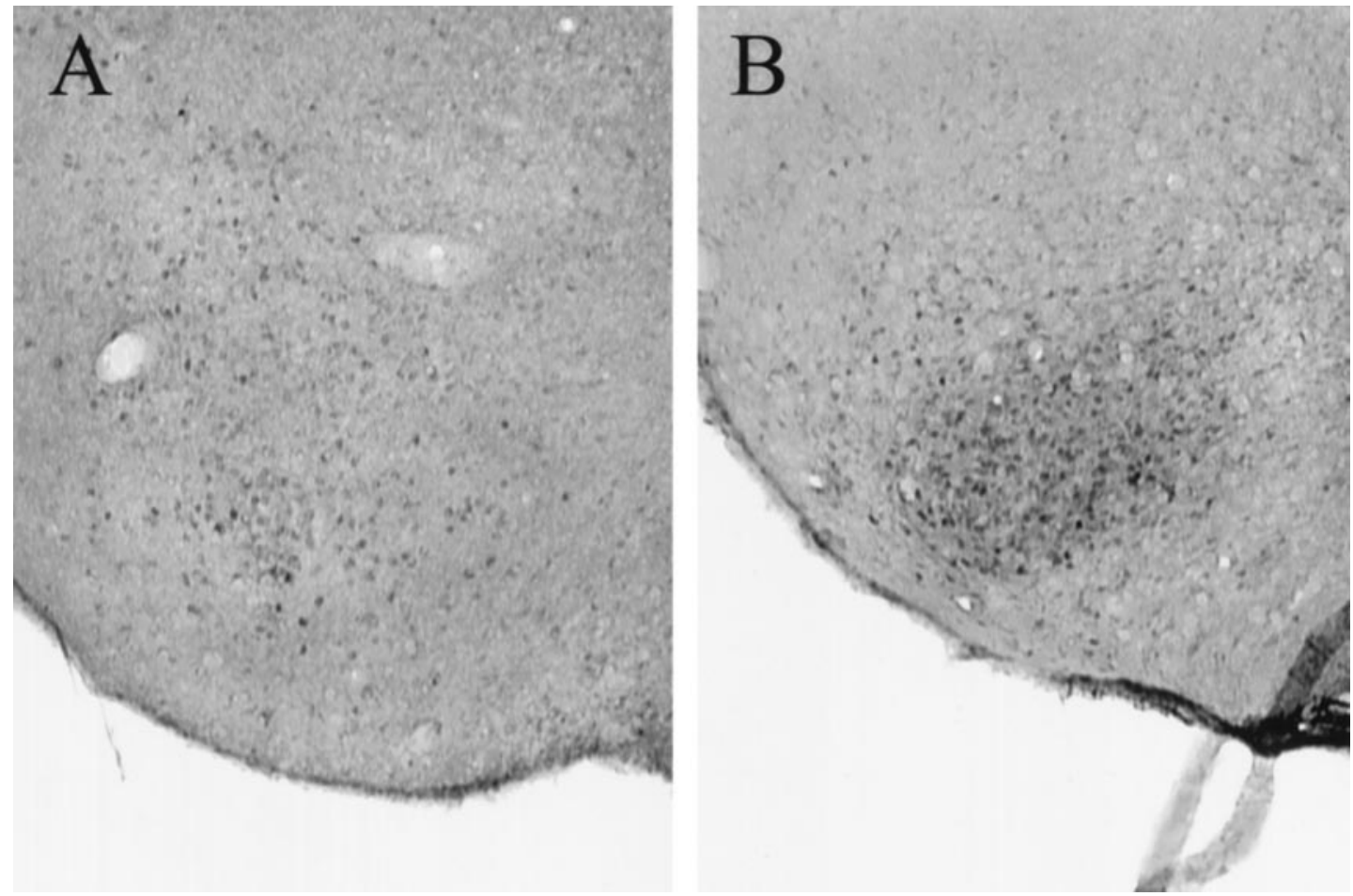

Figure 4. Photomicrograph of pDARPP-32 immunoreactivity in the cVMHVL $1 \mathrm{hr}$ after control stimulation $(A)$ and $1 \mathrm{hr}$ after experimenter-induced $\operatorname{VCS}(B)$.

tic nucleus and the bed nucleus of stria terminalis (Allen et al., 1981). Finally, VCS alters neuronal firing within the ventromedial hypothalamus of female rats (Chan et al., 1984). Based on the present results and the finding that $\mathrm{D}_{1}$ receptor stimulation induces immediate early protein expression in these areas, it is possible that the phosphorylation of DARPP-32 may be involved in some of these responses to VCS.

In summary, the results suggest that VCS causes an increase in phosphorylation of DARPP-32 in progestin receptor-containing areas of the rat forebrain. These results are consistent with the observation that VCS and/or mating induces changes in dopaminergic transmission in these areas such as the release of dopamine in the rat forebrain (Vathy and Etgen, 1989; Pfaus et al., 1995). The results are also consistent with observations that $\mathrm{D}_{1}$ agonists stimulate similar areas of the brain (Meredith et al., 1997), and that $\mathrm{D}_{1}$ agonists induce lordosis via a progestin receptormediated event (Mani et al., 1994; Apostolakis et al., 1996). Together, these results suggest an important step in the neuronal process by which VCS and other social and environmental stimuli may induce changes in neuronal function in populations of neurons.

\section{REFERENCES}

Allen TO, Adler NT, Greenberg JH, Reivich M (1981) Vaginocervical stimulation increases metabolic activity in the rat brain. Science 211:1070-1072.

Apostolakis EM, Garai J, Fox C, Smith CL, Watson SJ, Clark JH, O'Malley BW (1996) Dopaminergic regulation of progesterone receptors: brain $\mathrm{D}_{5}$ dopamine receptors mediate induction of lordosis by $\mathrm{D}_{1}$-like agonists in rats. J Neurosci 16:4823-4834.

Ariano MA, Sibley DR (1994) Dopamine receptor distribution in the rat CNS: elucidation using anti-peptide antisera directed against $\mathrm{D}_{1 \mathrm{a}}$ and $\mathrm{D}_{3}$ subtypes. Brain Res 649:95-110.
Auger AP, Moffatt CA, Blaustein JD (1996) Reproductively relevant stimuli induce Fos-immunoreactivity within progestin receptorcontaining neurons in localized regions of female rat forebrain. J Neuroendocrinol 8:831-838.

Auger AP, Moffatt CA, Blaustein JD (1997) Progesterone-independent activation of rat brain progestin receptors by reproductive stimuli. Endocrinology 138:511-514.

Barbas H, Gustafson EL, Greengard P (1993) Comparison of the immunocytochemical localization of DARPP-32 and I-1 in the amygdala and hippocampus of the rhesus monkey. J Comp Neurol 334:1-18.

Blandau RJ, Boling JL, Young WC (1941) The length of heat in the albino rat as determined by the copulatory response. Anat Rec 79:453-463.

Blaustein JD, Olster DH (1989) Gonadal steroid hormone receptors and social behaviors. In: Advances in comparative and environmental physiology (Balthazart J, ed), pp 31-104. Berlin: Springer.

Boling JL, Blandau RJ (1939) The estrogen-progesterone induction of mating responses in the spayed female rat. Endocrinology 25:359-364.

Boyson SJ, McGonigle P, Molinoff PB (1986) Quantitative autoradiographic localization of the $\mathrm{D}_{1}$ and $\mathrm{D}_{2}$ subtypes of dopamine receptors in rat brain. $\mathrm{J}$ Neurosci 6:3177-3188.

Chan A, Dudley CA, Moss RL (1984) Hormonal and chemical modulation of ventromedial hypothalamic neurons responsive to vaginocervical stimulation. Neuroendocrinology 38:328-336.

Coopersmith C, Gans SE, Rowe DW, Erskine MS (1996) Infusions of lidocaine into the amygdala, but not the preoptic area, block pseudopregnancy in the rat. J Neuroendocrinol 8:259-266.

Crowley WR, Jacobs R, Volpe J, Rodriguez-Sierra JF, Komisaruk BR (1976) Analgesic effect of vaginal stimulation in rats: modulation by graded stimulus intensity and hormones. Physiol Behav 16:483-488.

Crowley WR, Rodriguez-Sierra JF, Komisaruk BR (1977) Monoaminergic mediation of the antinociceptive effect of vaginal stimulation in rats. Brain Res 137:67-84.

Desduoits F, Cohen D, Nairn AC, Greengard P, Girault J (1995) Phosphorylation of DARPP-32, a dopamine- and cAMP-regulated phosphoprotein, by casein kinase I in vitro and in vivo. J Biol Chem 270:8772-8778.

Erskine MS (1989) Solicitation behavior in the estrous female rat: a review. Horm Behav 23:473-502. 
Erskine MS (1993) Mating-induced increases in FOS protein in preoptic area and medial amygdala of cycling female rats. Brain Res Bull 32:447-451.

Flanagan LM, Pfaus JG, Pfaff DW, McEwen BS (1993) Induction of fos immunoreactivity in oxytocin neurons after sexual activity in female rats. Neuroendocrinology 58:352-358.

Foreman MM, Moss RL (1979) Role of hypothalamic dopaminergic receptors in the control of lordosis behavior in the female rat. Physiol Behav 22:283-289.

Fremeau RTJ, Duncan GE, Fornaretto M, Dearry A, Gingrich JA, Breese GR, Caron MG (1991) Localization of $\mathrm{D}_{1}$ dopamine receptor mRNA in brain supports a role in cognitive, affective, and neuroendocrine aspects of dopaminergic transmission. Proc Natl Acad Sci USA 88:3772-3776.

Greengard P, Nairn AC, Girault J, Ouimet CC, Snyder GL, Fisone G, Allen PB, Feinberg A, Nishi A (1998) The DARPP-32/protein phosphatase-1 cascade: a model for signal integration. Brain Res Rev 26:274-284.

Hardy DF, DeBold JF (1973) Effects of repeated testing on sexual behavior of the female rat. J Comp Physiol Psychol 85:195-202.

Hemmings HC, Walaas SI, Ouimet CC, Greengard P (1987) Dopaminergic regulation of protein phosphorylation in the striatum: DARPP32. Trends Neurosci 10:377-383.

Huang Q, Zhou D, Chase K, Gusella JF, Aronin N, DiFiglia M (1992) Immunohistochemical localization of the $\mathrm{D}_{1}$ dopamine receptor in rat brain reveals its axonal transport, pre- and postsynaptic localization, and prevalence in the basal ganglia, limbic system, and thalamic reticular nucleus. Proc Natl Acad Sci USA 89:11988-11992.

Komisaruk BR (1972) Induction of lordosis in ovariectomized rats by stimulation of the vaginal cervix: hormonal and neural interrelationships. UCLA Forum Med Sci 15:127-135.

Komisaruk BR, Diakow C (1973) Lordosis reflex intensity in rats in relation to the estrous cycle, ovariectomy, estrogen administration, and mating behavior. Endocrinology 93:548-557.

Komisaruk BR, Wallman J (1977) Antinociceptive effects of vaginal stimulation in rats: neurophysiological and behavioral studies. Brain Res 137:85-107.

Langley KC, Bergson C, Greengard P, Ouimet CC (1997) Colocalization of the $\mathrm{D}_{1}$ dopamine receptor in a subset of DARPP-32containing neurons in rat caudate putamen. Neuroscience 78:977-983.

Levey AI, Hersch SM, Rye DB, Sunahara RK, Niznik HB, Kitt CA, Price DL, Maggio R, Brann MR, Ciliax BJ (1993) Localization of $D_{1}$ and $\mathrm{D}_{2}$ dopamine receptors in brain with subtype-specific antibodies. Proc Natl Acad Sci USA 90:8861-8865.

Lopez HC, Carrer HF (1982) Investigation of peripeduncular-hypothalamic pathways involved in the control of lordosis in the rat. Brain Res 253:287-302.

Mani SK, Allen JMC, Blaustein JD, Clark JH, O'Malley BW (1994) Convergent pathways for steroid hormone and neurotransmitterinduced rat sexual behavior. Science 265:1246-1249.

Mansour A, Meador-Woodruff JH, Bunzow JR, Civelli O, Akil H, Watson SJ (1990) Localization of dopamine $\mathrm{D}_{2}$ receptor mRNA and $\mathrm{D}_{1}$ and $\mathrm{D}_{2}$ receptor binding in the rat brain and pituitary: an in situ hybridization receptor autoradiographic analysis. J Neurosci 10:2587-2600.

Meisel RL, Camp DM, Robinson TE (1993) A microdialysis study of ventral striatal dopamine during sexual behavior in female Syrian hamsters. Behav Brain Res 55:151-157.

Meredith JM, Auger AP, Blaustein JD (1997) $\mathrm{D}_{1}$ dopamine receptor agonist (SKF-38393) induction of Fos immunoreactivity in progestin receptor-containing areas of female rat brain. J Neuroendocrinol 9:385-394.

Moss RL, Foreman MM (1976) Potentiation of lordosis behavior by intrahypothalamic infusion of synthetic luteinizing hormone-releasing hormone. Neuroendocrinology 20:176-181.

Ouimet CC, Miller PE, Hemmings HC, Walaas SI, Greengard P (1984) DARPP-32, a dopamine- and adenosine- $3^{\prime}, 5^{\prime}$-monophosphateregulated phosphoprotein enriched in dopamine-innervated brain regions. III. Immunocytochemical localization. J Neurosci 4:111-124.
Parsons B, Rainbow TC, MacLusky NJ, McEwen BS (1982) Progestin receptor levels in rat hypothalamic and limbic nuclei. J Neurosci 2:1446-1452.

Pfaff DW, Schwartz-Giblin S, McCarthy MM, Kow L (1994) Cellular and molecular mechanisms of female reproductive behaviors. In: The physiology of reproduction (Knobil E, Neill JD, eds), pp 107-220. New York: Raven.

Pfaus JG, Kleopoulos SP, Mobbs CV, Gibbs RB, Pfaff DW (1993) Sexual stimulation activates c-fos within estrogen-concentrating regions of the female rat forebrain. Brain Res 624:253-267.

Pfaus JG, Damsma G, Wenkstern D, Fibiger HC (1995) Sexual activity increases dopamine transmission in the nucleus accumbens and striatum of female rats. Brain Res 693:21-30.

Polston EK, Erskine MS (1995) Patterns of induction of the immediateearly genes $c$-fos and egr-1 in the female rat brain following differential amounts of mating stimulation. Neuroendocrinology 62:370-384.

Power RF, Mani SK, Codina J, Conneely OM, O'Malley BW (1991) Dopaminergic and ligand-independent activation of steroid hormone receptors. Science 254:1636-1639.

Power RF, Conneely OM, O'Malley BW (1992) New insights into activation of the steroid hormone receptor superfamily. Trends Pharmacol Sci 13:318-323.

Powers JB (1970) Hormonal control of sexual receptivity during the estrous cycle of the rat. Physiol Behav 5:831-835.

Rajendren G, Moss RL (1993) The role of the medial nucleus of amygdala in the mating-induced enhancement of lordosis in female rats- the interaction with luteinizing hormone-releasing hormone neuronal system. Brain Res 617:81-86.

Rowe DW, Erskine MS (1993) c-fos proto-oncogene activity induced by mating in the preoptic area, hypothalamus, and amygdala in the female rat-role of afferent input via the pelvic nerve. Brain Res 621:25-34.

Smith MS, Freeman ME, Neill JD (1975) The control of progesterone secretion during the estrous cycle and early pseudopregnancy in the rat: prolactin, gonadotropin, and steroid levels associated with rescue of the corpus luteum of pseudopregnancy. Endocrinology 96:219-226.

Snyder GL, Girault JA, Chen JY, Czernik AJ, Kebabian JW, Nathanson JA, Greengard P (1992) Phosphorylation of DARPP-32 and protein phosphatase inhibitor-1 in rat choroid plexus: regulation by factors other than dopamine. J Neurosci 12:3071-3083.

Snyder GL, Fisone G, Greengard P (1994) Phosphorylation of DARPP-32 is regulated by GABA in rat striatum and substantia nigra. J Neurochem 63:1766-1771.

Sunahara RK, Guan H, O’Dowd BR, Seeman P, Laurier LG, Ng G, George SR, Torchia J, Van Tol HHM, Niznik HB (1991) Cloning of the gene for a human dopamine $\mathrm{D}_{5}$ receptor with higher affinity for dopamine than $\mathrm{D}_{1}$. Nature 350:614-619.

Tetel MJ, Getzinger MJ, Blaustein JD (1993) Fos expression in the rat brain following vaginal-cervical stimulation by mating and manual probing. J Neuroendocrinol 5:397-404.

Tsou K, Snyder GL, Greengard P (1993) Nitric oxide/cGMP pathway stimulates phosphorylation of DARPP-32, a dopamine- and cAMPregulated phosphoprotein, in the substantia nigra. Proc Natl Acad Sci USA 90:3462-3465.

Vathy I, Etgen AM (1989) Hormonal activation of female sexual behavior is accompanied by hypothalamic norepinephrine release. J Neuroendocrinol 1:383-388.

Walaas SI, Greengard P (1984) DARPP-32, a dopamine- and adenosine $3^{\prime}, 5^{\prime}$-monophosphate-regulated phosphoprotein enriched in dopamineinnervated brain regions. I. Regional and cellular distribution in the rat brain. J Neurosci 4:84-98.

Walaas SI, Aswad DW, Greengard P (1983) A dopamine- and cyclic AMP-regulated phosphoprotein enriched in dopamine-innervated brain regions. Nature 301:69-71.

Weiner DM, Levey AI, Sunahara RK, Niznik HB, O'Dowd BF, Seeman $P$, Brann MR (1991) $D_{1}$ and $D_{2}$ dopamine receptor mRNA in rat brain. Proc Natl Acad Sci USA 88:1859-1863.

Whalen RE (1974) Estrogen-progesterone induction of mating in female rats. Horm Behav 5:157-162. 